\title{
The Protection of Non-nationals' Economic, Social and Cultural Rights in UN Human Rights Treaties
}

\author{
Claire Lougarre \\ Lecturer in Law; Director, Centre for Health Ethics and Law, University of \\ Southampton, Southhampton, United Kingdom \\ c.lougarre@soton.ac.uk
}

\begin{abstract}
The decade of austerity policies resulting from the 2008 economic crisis significantly impeded the realisation of economic, social and cultural (ESC) rights worldwide, especially for non-nationals who became targets of populist nationalist ideologies. The Coronavirus disease (COvID-19) pandemic and its subsequent recession have heightened existing levels of inequalities, putting non-nationals' access to health, housing, food, water and work under unprecedented strains. It is thus, crucial to analyse the extent to which UN human rights treaties recognise non-nationals' ESC rights, in order to assess their ability to offer protection in this context. This article sheds light on the ambiguities of key UN human rights treaties in this regard. It then analyses the attempts of relevant UN treaty bodies to circumvent such issues; and finally suggests legal paths allowing UN treaty bodies to further assert their protection of non-nationals' ESC rights during the COVID-19 pandemic.
\end{abstract}

\section{Keywords}

UN human rights treaties - economic, social and cultural rights - non-nationals - UN treaty bodies - treaty interpretation - Coronavirus disease (COVID-19) pandemic

As the world was slowly rising from the ashes of the 2008 economic crisis, following a decade of austerity policies that marginalised the most vulnerable groups of society, the CoviD-19 pandemic plunged it in the largest global 
recession in modern history and cruelly heightened pre-existing inequalities. ${ }^{1}$ This context is particularly worrying for non-nationals (i.e. refugees, asylumseekers, stateless persons, undocumented and documented migrants), whose rights to health, work, adequate housing, adequate food and water are experiencing unprecedented strains.

Over the past decade of austerity, 'foreigners' have often been blamed for social and economic ills, while also being worst affected by austerity policies based on populist nationalist ideologies. The UN Special Rapporteur on Contemporary Forms of Racism, Racial Discrimination, Xenophobia and Related Intolerance qualified this phenomenon the economic scapegoating of noncitizens'; ${ }^{2}$ while human rights bodies, NGOs and scholars overwhelmingly reported the particular impact this has had on rights such as health, work, adequate housing, adequate food and water. In 2020, the world became shook to its core by the Coronavirus disease (COvID-19) pandemic, triggering even higher levels of xenophobia. ${ }^{3}$ In a recent Guidance Note on the Impacts of the Covid-19 Pandemic on the Human Rights of Migrants, key UN human rights experts warned that 'the COVID-19 pandemic is having serious and disproportionate effects on migrants and their families globally', insisting on their insufficient access to health, education, work and social assistance; and the fact this resulted in the 'highest levels of contagions and deaths.'

It is, therefore, crucial that international human rights law reflects on the degree of protection it offers to non-nationals' economic, social and cultural rights (ESC rights). The existence of international legally binding treaties and monitoring bodies in the UN offers far-reaching legal tools to combat discriminatory policies at national levels. This article thus, analyses to what extent UN human rights treaties can contribute to protecting non-nationals' ESC rights,

1 World Bank, Global Economic Prospects (2020) <https://www.worldbank.org/en/publication/ global-economic-prospects $>$ accessed 9 September 2020, 13-20 (Box 1); United Nations Development Programme, Brief\#2: Putting the UN Framework for Socio-Economic Response to covID-19 into Action: Insights (2020) <https:/www.undp.org/content/undp/en/home/ coronavirus/socio-economic-impact-of-covid-19.html> accessed 9 September 2020, 11.

2 Special Rapporteur on contemporary forms of racism, racial discrimination, xenophobia and related intolerance, 'Report to the Human Rights Council' (25 April 2018) UN Doc. A/HRC $/ 38 / 52$, paras $60-62$.

3 Human Rights Watch, Covid-19 Fueling Anti-Asian Racism and Xenophobia Worldwide (2020) $<$ https://www.hrw.org/news/2020/05/12/covid-19-fueling-anti-asian-racism-and-xenophobia-worldwide $>$ accessed 9 September 2020.

4 UN Committee on the Protection of the Rights of All Migrant Workers and Members of their Families (CMW) and UN Special Rapporteur on the human rights of migrants, Joint Guidance Note on the Impacts of the CoviD-19 Pandemic on the Human Rights of Migrants (2020) $<$ https://www.ohchr.org/Documents/Issues/Migration/CMWSPMJointGuidanceNoteCOVID-19Migrants.pdf $>$ accessed 9 September 2020, 1. 
by focusing on two instruments of particular relevance, namely the International Covenant on Economic, Social and Cultural Rights (ICESCR); 5 and the International Convention on the Protection of the Rights of All Migrant Workers and Members of Their Families (ICMW). ${ }^{6}$

This article begins by discussing the limited protection offered by un human rights treaties, considering the legal ambiguities and uncertainty surrounding non-nationals' ESC rights in the text of the ICESCR and the ICMW. By doing so, it highlights drafting processes torn between universal aspirations and political realities. This article then thoroughly analyses how the two UN treaty bodies mandated to monitor the ICESCR and the ICMW interpret these conflicting norms. Such an analysis sheds light on their efforts to protect nonnationals' ESC rights but also on their failure to explicitly challenge ambiguous treaty provisions.

Finally, this article suggests legal avenues allowing UN treaty bodies to justify more convincingly States' obligations to fully realise the ESC rights of all non-nationals. Grounded in public international law, these recommendations offer further legal certainty and enhance the credibility of UN treaty bodies as quasi-judicial, transparent and accountable institutions. This article stresses the importance for international human rights law to deliver its promises of dignity and equality for all, especially in the midst of a pandemic, by learning from past mistakes.

\section{Limited Protection of Non-nationals' Economic, Social and Cultural Rights by un Human Rights Treaties}

This section explores to what extent UN human rights treaties can contribute to protecting non-nationals' ESC rights, strained by a decade of austerity and currently, by the CoviD-19 pandemic. To set the context, it begins by examining the text of relevant treaties on ESC rights of non-nationals. It reveals that despite their inherently universal scope, UN human rights treaties allow States to make differential treatments based on citizenship, including in two treaties key to the protection of non-nationals' ESC rights - the ICESCR, adopted in 1966; and the ICMW, adopted in 1990.

5 International Covenant on Economic, Social and Cultural Rights 1966, 993 UNTs 3 (ICESCR).

6 International Convention on the Protection of the Rights of All Migrant Workers and Members of Their Families 1990, 2220 UNTS 93 (ICMW). 


\subsection{The Universal Scope of UN Human Rights Treaties}

The universality of human rights values such as fairness, dignity and equality has been profusely evidenced in legal scholarship, ${ }^{7}$ and transpires from the existence of human rights norms and procedures at various regional and national levels. The universality of these values also embraces an aspect worth reemphasising in times of crises, since these are often connected to a rise of xenophobia: the timeless protection of non-nationals across the globe. Despite non-nationals suffering from a long history of prejudice, communities as well as States have increasingly perceived them as vulnerable individuals worthy of protection, over the past centuries. ${ }^{8}$ Weissbrodt argues that values of hospitality have been present in many ancient cultures, and that these values progressively mutated into clearer forms of protection. ${ }^{9}$ For instance, collective privileges were granted to 'alien merchants' under Medieval European feudal states, and the rule of 'Ubuntu' required that 'strangers' be given food, water, and shelter in traditional African societies. ${ }^{10}$ Legal thinkers later formalised these ad hoc forms of protection through the natural rights doctrine during the Enlightenment, or through the guarantee of diplomatic protection to 'foreigners' in the early days of international law. ${ }^{11}$

When the League of Nations was created, States attempted to protect nonnationals by drafting international treaties intended to prevent conflicts triggered by States oppressing 'new' national minorities inhabiting them, following a modification of their borders. ${ }^{12}$ While these treaties initially aimed at avoiding inter-States conflicts, they highlight that States recognised nonnationals as a vulnerable group. The Minorities Treaty between the Principal Allied and Associated Powers and Poland 1919, for instance, became a model for all minorities treaties. ${ }^{13}$ Its Article 2 recognises that all 'inhabitants' should

7 E.g., A Sen, Human Rights and Asian Values (Carnegie Council on Ethics and International Affairs 1997).

8 DS Weissbrodt, The Human Rights of Non-Citizens (Oxford University Press, 2008), 18-27; Del Vecchio, 'The Evolution of Hospitality: A Note on the History of the Treatment of Foreigners' (1963) 4 Sydney Law Review 205.

9 Weissbrodt, (n 8), 18-27.

10 Ibid.

11 Ibid.

12 C Weisbrod, 'Minorities and Diversities: The Remarkable Experiment of the League of Nations' (1993) 8 Connecticut Journal of International Law 359, 367-368.

13 Ibid, 368 . Minorities Treaty between the Principal Allied and Associated Powers (the British Empire, France, Italy, Japan and the United States) and Poland (signed 28 June 1919) (Minorities Treaty). 
be guaranteed the right to life and liberty, as well freedom of religion, without any distinction based on nationality. ${ }^{14}$

The protection afforded to non-nationals by the international community of States continued through the creation of the United Nations, starting with the UN Charter itself. ${ }^{15}$ Its Article 55(3), for instance, pursues the efforts of the League of Nations to promote rights for all to prevent cycles of fear, hatred, segregation, identity, rebellion and violence. ${ }^{16}$ It clearly states:

With a view to the creation of conditions of stability and well-being which are necessary for peaceful and friendly relations among nations based on respect for the principle of equal rights and self-determination of peoples, the United Nations shall promote: [...] universal respect for, and observance of, human rights and fundamental freedoms for all without distinction as to race, sex, language, or religion. ${ }^{17}$

Article 55(3) has been used as a basis to the drafting of key UN human rights treaties, all of which protect non-nationals' rights through their universal scope. This is evidenced by the repetition of words such as 'everyone' or 'every human beings' in their preambles and provisions, and by the appearance of clauses of non-discrimination in their text. ${ }^{18}$

14 Minorities Treaty, Article 2.

15 Charter of the United Nations 1945, 1 UNTS XVI (UN Charter).

16 See further discussions on the "solitarist" approach to human identity in: A. Sen, Identity and Violence: The Illusion of Destiny (Penguin Books, 2007).

17 UN Charter, Article 55(3).

18 Non-discrimination clauses in the UDHR and UN human rights treaties: Universal Declaration of Human Rights 1948, UNGA Res 217 A(III) (UDHR), Article 2; International Convention on the Elimination of All Forms of Racial Discrimination 1966, 660 UNTS 195 (ICERD), Article 1; International Covenant on Civil and Political Rights 1966, 999 UNTS 171 (ICCPR), Article 2(1); ICESCR, Article 2(2); Convention on the Elimination of All Forms of Discrimination Against Women 1979, 1249 UNTS 13 (CEDAW), Article 1; Convention against Torture and Other Cruel, Inhuman or Degrading Treatment or Punishment 1984, 1465 UNTS 85 (CAT), Article 1(1) (briefly mentioned); Convention on the Rights of the Child 1989, 1577 UNTS 3 (CRC), Article 2(1); ICMW, Article 7; Convention on the Rights of Persons with Disabilities 2006, 2515 UNTS 3 (CRPD), Article 4(1). (The only UN core human rights treaty that does not enclose the principle of non-discrimination in a specific provision is the International Convention for the Protection of All Persons from Enforced Disappearance 2006, 2716 UNTS 3. However, it recognises this principle in its Preamble). Nondiscrimination clauses in key UN treaties on non-nationals, and in regional treaties protecting ESC rights: Convention relating to the Status of Refugees 1951, 189 UNTS 137 (Refugee Convention), Preamble; Convention relating to the Status of Stateless Persons 1954, 36o UNTS 117 (Stateless Persons Convention), Preamble; European Social Charter (as amended) 1996, ETs No. 163 (European Social Charter), Article E.; Additional Protocol to 
While Un Member States have not adopted a human rights treaty specific to the protection of non-nationals' ESC rights, they have adopted a general ESC rights treaty (i.e. the ICESCR), which applies to everyone, and various treaties protecting non-nationals including a core human rights treaty (i.e. the ICMW), which contain ESC rights provisions. Both the ICESCR and the ICMW are seemingly embedded in the universality that characterises UN human rights treaties. The ICESCR, for instance, declares that the 'inalienable' rights it enshrines 'derive from the inherent dignity of the human person..$^{19}$ The preamble of the ICMW declares ' $\left[\mathrm{t}\right.$ ] aking into account' the principles embodied in the ICESCR ${ }^{20}$ thereby embracing its universal aspirations. Furthermore, in an extraordinary statement released on 24 March 2020, all UN Human Rights Treaty Bodies urged States to protect the rights to health and education of everyone in the midst of the COVID-19 pandemic, including 'refugees, asylum seekers and migrants.21 Therefore, it is reasonable to assume that UN human rights treaties, including the ICESCR and the ICMW, are grounded in universal aspirations and apply to non-nationals.

However, international human rights law fails to fully deliver on its universal promises when it comes to non-nationals' ESC rights. This is evidenced by the allowance of 'differential treatments based on citizenships' in relevant UN human rights treaties, a concept first introduced by Article 1(2) of the International Convention on the Elimination of All Forms of Racial Discrimination. ${ }^{22}$ This could jeopardise the best attempts of international human rights law if used in times of crisis such as the CoviD-19 pandemic.

the American Convention on Human Rights in the Area of Economic, Social and Cultural Rights 1988, oAs Treaty Series No 69 (1988) reprinted in Basic Documents Pertaining to Human Rights in the Inter- American System oEA/Ser L v/II.82 Doc 6 Rev 1 at 67 (1992) (Protocol of San Salvador), Article 3; African Charter on Human and Peoples' Rights 1981, 21 ILM 58 (African Charter), Article 2.

19 ICESCR, Preamble.

20 ICMW, Preamble.

21 OHCHR, UN Human Rights Treaty Bodies Call for Human Rights Approach in Fighting CovID-19 (Press Release) (2020) <https://www.ohchr.org/EN/NewsEvents/Pages/ DisplayNews.aspx?NewsID=25742\&LangID=E $>$ accessed on 9 September 2020.

ICERD, Article 1(2): 'This Convention shall not apply to distinctions, exclusions, restrictions or preferences made by a State Party to this Convention between citizens and noncitizens'. Its UN treaty body interpreted this provision as follows, in CERD, 'General Recommendation No. Xxx on Discrimination Against Non-Citizens' (1 October 2002) UN Doc. A/59/18, para 1: 'Article 1, paragraph 2 provides for the possibility of differentiating between citizens and non-citizens.' 
2.2

2.2.1

\section{The Ambiguous Protection of Non-nationals under the ICESCR}

Protection of Non-nationals in the ICESCR

At first glance, the ICESCR clearly protects non-nationals' ESC rights. Its preamble explicitly recognises that ESC rights 'derive from the inherent dignity of the human person, ${ }^{23}$ therefore extending the scope of this treaty to nonnationals. This wording is significant when assessing what the ICESCR means and how it ought to be applied, given the crucial role of preambles in treaty interpretation. Article 31(1) of the Vienna Convention on the Law of Treaties (VCLT) provides that a treaty 'shall be interpreted in good faith' in accordance with the text, context, as well as the object and purpose of treaties when interpreting them. ${ }^{24}$ Article $31(2)$ of the VCLT confirms that the 'context for the purpose of the interpretation of a treaty' comprise, among others the text, including its preamble and annexes. ${ }^{25}$ Gardiner rightly emphasises that given their role (i.e. 'stating the aims and objectives of a treaty'), preambles can be used to identify the 'object and purpose' of the treaty. ${ }^{26}$ However, as argued by Hulme, the role of preambles in treaty interpretation remains uncertain since it is unclear whether or not they embody a legal standard with which States must comply. ${ }^{27}$ Some States' representatives and academics contend that preambles are not capable of generating legal obligations per se, ${ }^{28}$ while others declare that they can (presumably, because the VCLT sets no limits on their legal power). ${ }^{29}$

Considering this ambivalence around preambles, relying on treaty provisions that outline more explicitly States' obligations to protect non-nationals' ESC rights in order to perform the ICESCR in 'good faith', ${ }^{30}$ offers more certainty. The prohibition of discrimination, enshrined in Article 2(2) of the

\footnotetext{
23 ICESCR, Preamble.

24 Vienna Convention on the Law of Treaties 1969, 1155 UnTS 331 (VCLT), Article 31(1).

25 Ibid, Article 31(2).

26 R Gardiner, Treaty Interpretation (2nd edn, Oxford University Press, 2017), 205-206: 'By stating the aims and objectives of a treaty, as preambles often do in general terms, they can help in identifying the object and purpose of the treaty'.

27 M Hulme, 'Preambles in Treaty Interpretation' (2016) 164 University of Pennsylvania Law Review 1281, 1284 (Part II) and 1342.

28 E.g. Opening statement of Us Senator John Kerry, Chairman of the Committee on Foreign Relations in 'The New START Treaty: Hearing Before the Senate Committee on Foreign Relations' (111th Congress 2nd session, 2010) <https://www.foreign.senate.gov/imo/ media/doc/New_START_hearings_111th_Congress.pdf > accessed 9 September 2020, 268: 'Obviously, the preamble is not legally binding'; Gardiner, (n 26), 206: 'The recitals in the preamble are not the appropriate place for stating obligations, which are usually in operative articles of the treaty or in annexes'.

29 Hulme, (n 27), 1287 (and Part II).

30 VCLT, Article 26.
} 
ICESCR, as well as the entitlement of 'everyone' to access each of the rights recognised by Articles 6 to 15 of the ICESCR, confirm that States parties must realise the rights of non-nationals. ${ }^{31}$ Article $2(2)$ of the ICESCR explicitly prohibits States from discriminating individuals on the basis of 'national [...] origin', and provides further protection by prohibiting 'discrimination of any kind' based on any 'other status.' ${ }^{32}$ Therefore, not only are States parties to the ICESCR prohibited from discriminating individuals depending on where they come from, they are also prohibited from discriminating individuals on the basis of their migration status. It is thus, surprising to observe ambiguities concerning the protection of non-nationals' ESC rights in the ICESCR.

\section{2 .2}

\section{Legal Ambiguities in the ICESCR}

When scrutinising the text of the ICESCR, it becomes apparent that this treaty does not protect non-nationals' ESC rights unconditionally. Its Article 2(3), in particular, states:

Developing countries, with due regard to human rights and their national economy, may determine to what extent they would guarantee the economic rights recognized in the present Covenant to non-nationals. ${ }^{33}$

However, if Article 2(3) is understood as allowing what would now be called 'middle-income countries' the discretion to determine the extent to which they would guarantee 'economic rights' such as the right to work to nonnationals, Article 2(3) of the ICESCR may clash with the universal scope of this treaty. As discussed above, such a universal scope is evidenced by the preamble of the ICESCR, its Article 2(2) on non-discrimination, and its Articles 6 to 8 on work rights. ${ }^{34}$ The existence of such a provision in a UN human rights treaty is particularly problematic in the current context, since the International Labour Organisation (ILO) recently declared: 'Migrant workers are often first to be laid-off but [...] are often excluded from national covid-19 policy responses, such as wage subsidies, unemployment benefits or social security and social protection measures.'. ${ }^{35}$

\footnotetext{
31 ICESCR, Articles 2(2) and 6-15.

32 Ibid, Article 2(2).

33 Ibid, Article 2(3).

34 Ibid, Preamble, Articles 2(2) and 6-8.

35 International Labour Organization (ILO), Protecting Migrant Workers during the COVID-19 Pandemic: Recommendations for Policy-Makers and Constituents (Policy Brief) (2020), <https://www.ilo.org/wcmsp5/groups/public/---ed_protect/---protrav/---migrant/ documents/publication/wcms_743268.pdf $>$ accessed 9 September 2020, 2.
} 
The study of the drafting process of the ICESCR (1950s-196os) reveals the irrelevance of Article 2(3) to our present situation. When examining the Travaux Préparatoires of this provision, Dankwa identified two types of concerns formulated by States representatives at the time, regarding nonnationals. ${ }^{36}$ The first type of concerns came from various States delegates who discussed the necessity to distinguish nationals from non-nationals regarding employment matters. The United Kingdom (UK) and the Netherlands, for instance, stressed the need to prioritise employment opportunities for nationals when resources were scarce. They argued that the principle of nondiscrimination, enshrined in Article 2(2) of the ICESCR, should be reconciled with this particular application of the principle of progressive realisation (enshrined in Article 2(1)). ${ }^{37}$ The discussion, nonetheless, was adjourned and no agreement was reached. ${ }^{38}$ The second type of concerns came from States delegates from 'developing' States that had recently accessed independence. These delegations expressed their worry that nationals from former colonising States who still resided on their territories, remained in control of their national economies and, therefore, threatened their autonomy. Indonesia and Burma observed that the application of Article 2(2) of the ICESCR would be problematic in this context and suggested that a new paragraph be included. ${ }^{39}$ This later became Article 2(3), following a very tight vote. ${ }^{40}$ Given the progress of the decolonisation process over the past 60 years and the global vulnerability of non-nationals to unemployment and unsafe working conditions following years of austerity and now, the CoviD-19 pandemic, the drafting history of Article 2(3) of the ICESCR seems irrelevant. However, it is unclear whether Article 2(3) could still be interpreted as allowing middle-income countries to restrict non-nationals' work rights due to insufficient resources, as the world has entered an unprecedented recession.

36 E. V. O. Dankwa, 'Working Paper on Article 2(3) of the International Covenant on Economic, Social and Cultural Rights' (1987) 9 Human Rights Quarterly 230, 231-236.

37 UNGA, 'Draft International Covenants on Human Rights, Report of the Third Committee, 655th meeting' (1955) UN Doc. A/C.3/sR.655, paras 17-22.

38 Dankwa, (n 36); ungA, 'Draft International Covenants on Human Rights, Report of the Third Committee, 659th meeting' (1955) un Doc. A/C.3ISR.659, para 44.

39 UNGA, 'Draft International Covenants on Human Rights, Report of the Third Committee, 1184th meeting' (1962) UN Doc. A/C.3/sR.1184, para 41; UNGA, 'Draft International Covenants on Human Rights, Report of the Third Committee, Annex (Agenda Item 43)' (1962) UN Doc. A/5365, para 68.

40 Dankwa, (n 36), 236: Article 2(3) of the ICESCR was adopted by forty-one votes to thirtyeight, with twelve abstentions. 


\subsection{The Ambiguous Protection of Non-nationals under the ICMW}

2.3.1 Protection of Economic, Social and Cultural Rights in the ICMW

Like the ICESCR, the ICMW clearly protects non-nationals' ESC rights at first glance, for two reasons. However, its scope is limited to migrants workers and, therefore, does not include asylum-seekers, refugees, stateless persons, and migrants who are unemployed (whose ESC rights are thus, mainly protected by the ICESCR).

Firstly, the ICMW contributes to protecting non-nationals' ESC rights because several of its provisions recognise the ESC rights of migrant workers (and their families). These include: the right to work (Article 25); the right to participate in trade unions (Articles 26 and 40); the right to social security (Article 27); the right to medical assistance (Article 28); the right to education (Article 30); the right to a cultural identity (Article 31); the right to housing (Article 43); the right to social services (Article 43); and the right to access cultural life (Article 43). ${ }^{41}$ Therefore, almost all the rights enshrined in the ICESCR are also enshrined in the ICMW, giving migrant workers a significant array of ESC rights protection.

Furthermore, Article 5(e) of the International Convention on the Elimination of All Forms of Racial Discrimination recognises a range of ESC rights. ${ }^{42}$ UN treaties protecting non-nationals' rights such the Refugee Convention 1951 or the Stateless Persons Convention 1954 do too, with provisions recognising the right to work (Articles 17-19, 24); the right to housing (Article 21); the right to education (Articles 22 and 43); the right to public relief (Article 23); and the right to social security (Article 24) ${ }^{43}$ The protection afforded by these three treaties confirms the desire of the international community to create States' obligations to realise non-nationals' ESC rights and highlights the relevance of the ICMW.

Secondly, the ICMW contributes to protecting non-nationals' ESC rights because it embraces universal aspirations in its text. The preamble of the ICMW requires that States provide 'appropriate international protection' for the rights of migrant workers (and members of their families) due to their 'situation of vulnerability, ${ }^{4}$ though controversy persists regarding the binding nature of preambles in treaty interpretation. Its Article 7 asserts more explicitly the universal scope of this treaty, by prohibiting States parties from discriminating individuals based on their 'nationality' or any 'other status' (thus, including

\footnotetext{
41 ICMW, Articles 25, 26, 27, 28, 30, 31, 40, 43 .

42 ICERD, Article 5(e).

43 Refugee Convention, Articles 17-19, 21, 22 and 24; Stateless Persons Convention, Articles 17-19, 21, 22 and 24; ICMW, Articles 25-31.

44 ICMW, Preamble.
} 
their migration status). ${ }^{45}$ The wording of Article 7 , nonetheless, is problematic: it only prohibits discrimination amongst migrant workers themselves ${ }^{46}$ and potentially allows States parties to reduce non-nationals' access to ESC rights, as long as that reduction affects all migrant workers equally. These concerns are alleviated by the recognition of a 'principle of equality of treatment with nationals' in various provisions of the ICMW, including those relevant to ESC rights. ${ }^{47}$ The preamble of the ICMW, altogether with its Article 7 and the principle of equality of treatment with nationals, impose an obligation upon States parties to not discriminate migrant workers in the realisation of their ESC rights. Furthermore, the Refugee Convention and the Stateless Convention prohibit discrimination based on 'country of origin',48 thereby stressing the relevance of these requirements in international human rights law more broadly, not only for migrant workers. Nevertheless, ambiguities persist in the text of the ICMW regarding the extent to which States parties are expected to realise the ESC rights of non-nationals.

\subsubsection{Legal Ambiguities in the ICMW}

When looking more closely at the ICMW, it appears that - like the ICESCR - its protection of non-nationals' ESC rights is ambiguous (though for different reasons).

The first ambiguity lies with the text of the ICMW, as its provisions are more protective towards documented migrant workers than towards undocumented migrant workers. The ICMW recognises that all migrant workers (including undocumented migrant workers) are entitled to a number of 'minimal' ESC rights. These include: the right to remuneration; trade union rights; the right to social security; the right to emergency medical care; children's right to education; and the right to cultural identity. ${ }^{49}$ However, the ICMW reserves certain additional ESC rights to migrants working lawfully within the territory of States

45 Ibid, Article 7.

46 This is also argued by S Hune and J Niessen, 'The First Un Convention on Migrant Workers' (1991) 9 Netherlands Quarterly of Human Rights 130, 135: 'It is not, however, a general anti-discrimination clause because it relates only to the rights enumerated in the Convention'.

ICMW, Articles 25, 27, 28, 30 (regarding all migrant workers); and Articles 43, 45, 54, 55 (regarding documented migrant workers). The only ESC rights that are not protected by the principle of equality of treatment with nationals are: trade union rights and the right to a cultural identity in Articles 26 and 31 (for all migrant workers); as well as the right to freely choose a remunerated activity and the right to family protection in Articles 44 and $5^{2}$ (for documented migrant workers).

48 Refugee Convention, Article 3; Stateless Persons Convention, Article 3.

49 ICMW, Articles 25, 26, 27, 28, 30, 31. 
parties. Therefore, rights such as adults' right to education, the right to housing, the right to health services, the right to access and participate to cultural life, the right to family protection, the right to freely choose a remunerated activity, unemployment rights, or the right to exercise a remunerated activity, do not apply to undocumented migrants. ${ }^{50}$ This is particularly worrying given the significant impact of the COVID-19 pandemic on undocumented workers, most of whom are women: they are often the first to loose their jobs and the last to obtain adequate wages or social protection, including sickness-related benefits. ${ }^{51}$

The second ambiguity regarding the protection of non-nationals' ESC rights in the ICMW is its legal context, since the scope of some ESC rights recognised in the ICMW is narrower than in the ICESCR. For instance, Article 12 of the ICESCR understands the right to health as 'the right of everyone to the enjoyment of the highest attainable standard of physical and mental health, ${ }^{52}$ while Article 28 of the ICMW limits it to 'emergency medical care' for undocumented migrants. ${ }^{53}$ Work rights are laid out in similar terms in both the ICESCR and the ICMW (except the right to strike, which is only recognised by the ICESCR), but are framed under more constraining conditions under the ICMW. ${ }^{54}$ These discrepancies highlight that non-nationals residing in States parties to both the ICESCR and the ICMW would not receive the same degree of protection if they were to rely on the ICMW. This is particularly problematic since the two maxims generally accepted in international law on how to interpret treaties dealing with the same subject, both give prevalence to the ICMW. The first maxim suggests that the more recent norm prevails ('lex posterior derogat legi priori', encapsulated in Article 30 VCLT). ${ }^{55}$ This would give priority to the ICMW, adopted in 1990, over the ICESCR, adopted in 1966. The second maxim suggests that the more specific norm prevails ('ex specialis derogat legigenerali', encapsulated in international case law). ${ }^{56}$ Again, this would give priority to the ICMW since the latter is a specific UN human rights treaty dealing with

$50 \quad$ Ibid, Articles 43, 44, 45, 52, 54, 55 .

51 ILO, (n 35), p. 2.

$5^{2} \quad$ ICESCR, Article 12.

53 ICMW, Article 28. See also: CERD, 'General Recommendation No. XXX on Discrimination Against Non-Citizens', (n 22), para 36, in which the UN Committee on the Elimination of Racial Discrimination urges States to provide non-citizens with an 'adequate' standard of health.

54 ICMW, Articles 25, 26, 40, $5^{2}$ and 55; ICESCR, Articles 6, 7 and 8.

55 VCLT, Article 30.

56 See the maxim being applied to norms existing in two different international instruments: Mavrommatis Palestine Concessions (Greece v United Kingdom) (Merits, Objection to the Jurisdiction of the Court) 1924 PCIJ Series A, No. 2. 
migrants' rights, while the ICESCR belongs to the UN 'Bill of Rights' and recognises everyone's ESC rights. It is worth noting that this problem is not exclusive to the ICMW: other UN treaties protecting non-nationals' rights, such as the UN Refugee and the Stateless Persons Conventions, are less protective of nonnationals' ESC rights, even less than the ICMW itself. ${ }^{57}$

The ambiguities of the ICMW, nonetheless, must be understood in the light of the context during which the treaty was drafted, i.e. the 1980 os. Hune reports that the economic recession present during its drafting process triggered apprehension from countries traditionally 'hosting' migrants, regarding the costs of implementing ESC rights such as the right to education. ${ }^{58}$ Furthermore, political hostility subsided during the decades following the adoption of the ICMW, impeding its ratification process and thereby, weakening its significance on the UN platform. The political instability and the migration flux generated by the restructuring of the Soviet Union and Eastern Europe, as well as the rise of Islamic fundamentalism, impeded the ratification of the ICMW in the 1990s according to Hune and Niessen:59 only 12 States became parties to this treaty between 1990 and $1999 .{ }^{60}$ More recently, the financial crisis of 20072008, the significant number of persons displaced due to conflicts in Syria, Afghanistan or South Sudan, as well as the increased flux of migrants generated by globalisation, contributed to a rise of xenophobia and a lack of political willingness to protect non-nationals effectively: most States became parties to the ICMW between 2000 and 2008 , but very few after. ${ }^{61}$ So far, this instrument only counts 55 ratifications, ${ }^{62}$ mostly from low and middle-income countries that tend to 'send' migrants more than 'host' them. ${ }^{63}$ This outcome does not

57 Refugee Convention; Stateless Persons Convention: unlike the ICMW, they do not recognise explicitly trade union rights, the right to family protection and assistance, or the right to health.

$5^{8}$ S Hune, 'Drafting an International Convention on the Protection of the Rights of All Migrant Workers and Their Families' (1987) 21 International Migration Review 123, 126; Hune and Niessen (1991), (n 46), 134 .

59 S Hune and J Niessen, 'Ratifying the un Migrant Workers Convention: Current Difficulties and Prospects' (1994) 12 Netherlands Quarterly of Human Rights 393, 397-398; Un Treaty Collection, Status of the International Convention on the Protection of the Rights of All Migrant Workers and Members of Their Families <https://treaties.un.org/pages/View Details.aspx?src=TREATY\&mtdsg_no=IV-13\&chapter=4\&clang=_en $>$ accessed 9 September 2020.

6o UN Treaty Collection, ICMW <https://treaties.un.org/Pages/ViewDetails.aspx?src= TREATY\&mtdsg_no=IV-13\&chapter $=4 \&$ clang $=\_$en $>($accessed 9 September 2020 $)$.

61 Ibid.

62 Ibid.

63 See a breakdown of 'hosting states' in International Organization for Migration, World Migration Report 2018 (2017) <https://www.iom.int/sites/default/files/country/ 
threaten the protection of non-nationals' ESC rights in theory, since migrant workers residing in hosting States not parties to the ICMW can continue to rely on the ICESCR, which is more protective. However, it threatens it in practice, by making a crucial legal and political tool, obsolete. In the midst of a pandemic threatening migrant workers' ESC rights in an unprecedented manner, the ICMW ought to lead by example.

In order to assess to what extent UN human rights treaties can contribute to protecting non-nationals' ESC rights in a period of crisis, this second section examined the text and origins of those treaties. It concluded that while UN human rights treaties intend to protect all human beings, they also allow States to treat non-nationals differently in certain circumstances, thereby conveying a confusing message. This was further demonstrated by focusing on the text of the ICESCR. While this treaty clearly protects the ESC rights of every human being, including non-nationals, its Article 2(3) is ambiguous regarding the protection of non-nationals in middle-income countries. Studying the text of the ICMW also revealed a degree of ambiguity. While various provisions of the ICMW recognise migrant workers' ESC rights, the scope of these provisions is restricted, especially when compared to that afforded by the ICESCR and regarding undocumented migrant workers. It is, therefore, crucial that this article now analyses how UN treaty bodies (bodies mandated to monitor the implementation of UN human rights treaties) interpret these conflicting norms, in order to assess their ability to protect non-nationals' EsC rights in the covid-19 context.

\section{3}

Opaque Protection by UN Treaty Bodies

Considering the strains created by a decade of austerity and, currently, by the COVID-19 pandemic on non-nationals' ESC rights, the ambiguous protection afforded by key UN human rights treaties such as the ICESCR and the ICMW, is worrying. This article will continue to assess to what extent UN human rights treaties can contribute to protecting non-nationals' ESC rights, but by examining how relevant UN treaty bodies have interpreted ambiguities in practice. This section, therefore, will shed light on the protection afforded by: the Committee on Economic, Social and Cultural Rights (the CESCR), which monitors the implementation of the ICESCR; and the Committee on the Protection of

docs/china/r5_world_migration_report_2018_en.pdf> accessed 9 September 2020, p. 19 (figure 2): key hosting states for international migrants; p. 21 (table 2): key hosting states for undocumented migrants; p. 34 (figure 7): key hosting states for refugees. 
the Rights of All Migrant Workers and Members of Their Families (the CMW), which monitors the implementation of the ICMW. This article will focus on the key authoritative documents through which these Committees interpret the ICESCR and the ICMW: General Comments and Concluding Observations. ${ }^{64}$ The CESCR and the CMW have released no General Comments or Concluding Observations since the beginning of the covid-19 pandemic. ${ }^{65}$ Therefore, this article will analyse how these UN treaty bodies interpreted non-nationals' ESC rights during a recent global crisis threatening their realisation, in order to assess their ability to offer protection during the current crisis. This section will reveal that during the decade of austerity that followed the 2008 economic crisis, both Committees dismissed problematic treaty provisions to further protect non-nationals' ESC rights, but without sufficiently justifying their rationale. Such a lack of transparency must thus, be remedied in order to provide a more sustainable protection to non-nationals' EsC rights during the COVID-19 crisis.

Protection of Non-nationals' Economic, Social and Cultural Rights by the CEscR

Explicit Protection of Non-nationals' Economic, Social and

Cultural Rights in General Comments

To appreciate how the CESCR (thereafter called 'the Committee' in this section) interprets the application of the ICESCR to non-nationals, it is worth studying first its General Comments. General Comments are documents in which UN treaty bodies clarify their interpretation of a provision or thematic issue relevant to the treaty they are mandated to monitor, and they have a quasi-authoritative status in international human rights law. By March 2020 the CESCR had issued 25 General Comments. All of them stress the particular importance of the principle of non-discrimination enshrined in Article 2(2) of

64 Communications will not be examined, given the limited findings offered by complaints procedures under these two treaties. The CESCR only started reviewing individual complaints in 2013 (date of entry into force of the Optional Protocol to the International Covenant on Economic, Social and Cultural Rights 2008, UN Doc A/REs/63/117). As a result, it has only held a limited number of Communications in which it has 'adopted views' so far (i.e. equivalent of decisions based on merits), and none of them were lodged by non-nationals. See the Jurisprudence database of the Un Office of the United Nations High Commissioner for Human Rights: <https://juris.ohchr.org/search/documents> accessed 9 September 2020. As for the CMW, it cannot review individuals complaints, given no Optional Protocol has been adopted yet to give it this power.

65 As of 9 September 2020, the only exception is CESCR, 'General Comment No. 25: Science and Economic, Social and Cultural Rights (Article 15 ICESCR)' (30 April 2020) UN Doc. E/C.12/GC/25, but it does not discuss non-nationals' ESC rights. 
the ICESCR, and the protection of disadvantaged and vulnerable groups. In General Comment 3 on 'The nature of States parties' obligations' and General Comment 20 on 'Non-Discrimination in Economic, Social and Cultural Rights', the Committee declares that the principle of non-discrimination represents an 'immediate obligation' for States parties to the ICESCR. ${ }^{66}$ This 'immediacy' highlights the need to protect vulnerable groups, since it departs from the general requirement under Article 2(1) of the ICESCR, according to which these rights are to be realised 'progressively' subject to maximum available resources. ${ }^{67}$

Moreover, the Committee declares that the principle of non-discrimination represents a 'core obligation' in General Comments 13 or 14 on the right to education and the right to health. ${ }^{68}$ This also emphasises the Committee's desire to firmly protect vulnerable groups, since core obligations capture the 'raison dêtre' of the ICESCR by setting minimum levels of ESC rights. ${ }^{69}$ More importantly for this article, the Committee explicitly recognises that non-nationals are a vulnerable group that ought to be protected by the principle of non-discrimination..$^{70}$ In General Comment 20 on 'Non-Discrimination in ESC rights', it declares that

[t]he ground of nationality should not bar access to Covenant rights', $[\ldots]$ ' $[\mathrm{t}]$ he Covenant rights apply to everyone including non-nationals, such as refugees, asylum-seekers, stateless persons, migrant workers and victims of international trafficking, regardless of legal status and documentation. ${ }^{71}$

However, the Committee inserts a footnote in that same quote, to specify that this paragraph should be understood 'without prejudice to the application' of Article 2(3) of the ICESCR (which allows 'developing countries' to determine to

66 CESCR, 'General Comment No. 3: The Nature of States Parties' Obligations (Article 2(1) ICESCR)' (14 December 1990) Un Doc. E/1991/23, annex III at 86 (1991), para 1; CESCR, 'General Comment No. 20: Non-Discrimination in Economic, Social and Cultural Rights (Article 2(2) ICESCR)' (2 July 2009) UN Doc E/C.12/GC/20, para 7.

67 ICESCR, Article 2(1).

68 CESCR, 'General Comment No. 13: The Right to Education (Article 13 ICESCR)' (8 December 1999) Un Doc. E/C.12/1999/10, para 57; CESCR, 'General Comment No. 14: The Right to the Highest Attainable Standard of Health (Article 12 ICESCR)' (11 May 2000) UN Doc. E/C.12/200o/4, para 43(a).

69 CESCR, General Comment 3, (n 66), para 10.

$70 \quad$ CESCR, General Comment 20, (n 66), paras 27 and 30.

71 Ibid, para 30. 
what extent they guarantee economic rights to non-nationals). ${ }^{72}$ While the drafting history of Article 2(3) initially stresses its irrelevance to our current context, the fact that the CESCR mentions it in a recent General Comment (2009) challenges this presumption. Will the Committee interpret this provision as allowing middle-income countries to restrict non-nationals' work rights in order to preserve resources reduced by the CoviD-19 recession? It seems unlikely when reading General Comment 3 on 'The nature of States parties' obligations', as the Committee reminds us that austerity cannot be used as an excuse for not realising non-nationals' Ecs rights:

even in times of severe resources constraints whether caused by a process of adjustment, of economic recession, or by other factors the vulnerable members of society can and indeed must be protected by the adoption of relatively low-cost targeted programmes. ${ }^{73}$

Nevertheless, it is unclear whether this statement allows States parties to the ICESCR to reduce non-nationals' ESC rights in times of severe resources constraints, as long as they ensure minimum standards. General Comment 20 on 'Non-Discrimination in ESC rights' seems to refute this possibility, by affirming that economic policies should not result in discrimination. ${ }^{74}$ However, the Committee does not clarify what constitutes discrimination based on national origin and how this ought to be interpreted in times of austerity. To conclude, while the General Comments of the Committee clarify that States parties to the ICESCR must realise non-nationals' ESC rights, it is unclear to what extent (compared to nationals). The same conclusion can be drawn from its CoviD-19 Statement, which urges States 'to protect the jobs, wages and benefits of all workers, including undocumented migrant workers', without specifying to what degree. ${ }^{75}$

Ad hoc Protection of Non-nationals' Economic, Social and Cultural Rights in Concluding Observations

This section will analyse the 158 Concluding Observations issued by the CESCR during the decade following the 2008 economic crisis, in an attempt to further

72 Ibid, footnote 22.

73 CESCR, General Comment 3, (n 66), para 12; CESCR, 'General Comment 14', (n 68), para 18.

74 CESCR, General Comment 20, (n 66), para 38: 'Economic policies, such as budgetary allocations and measures to stimulate economic growth, should pay attention to the need to guarantee the effective enjoyment of the Covenant rights without discrimination.'

75 CESCR, 'Statement on the Coronavirus Disease (covid-19) Pandemic and Economic, Social and Cultural Rights' (2020) 2 International Human Rights Law Review 135, para 15. 
assess how it interprets the application of the ICESCR to non-nationals in times of global austerity and thus, how it can protect their ESC rights during the Covid-19 crisis. Concluding Observations are documents in which UN treaty bodies periodically formulate comments for each State Party on the implementation of the treaty they are mandated to monitor, as part of their reporting procedure.

The first observation drawn from these Concluding Observations is that the Committee clearly assesses States parties' compliance with the ICESCR, by verifying that they do not discriminate against non-nationals. From 2008 to 2018, the Committee often requires that States fulfil non-nationals' ESC rights to a greater extent, regardless of individuals' migration status or country of origin. ${ }^{76}$ It often upholds the principle of non-discrimination during this exercise, but refers to Article 2(2) of the ICESCR in less than half of the cases (and never refers to the prohibited ground of 'national origin'). ${ }^{77}$ Furthermore, the Committee never refers to the universal scope of the ICESCR, enshrined in its Preamble, ${ }^{78}$ or the immediate and core aspects of the prohibition to discriminate, recognised in its General Comments. ${ }^{79}$ Therefore, the Committee fails to justify sufficiently its legal reasoning to prevent potential objections based on Article 2(3) of the ICESCR.

The second observation arising from the Committee's Concluding Observations is that it does not allow States to treat individuals differently based on their citizenship, thereby disregarding Article 2(3) of the ICESCR. From 2008 to 2018, the Committee never refers to Article 2(3), revealing its lack of interest or willingness to engage with this provision. It even dismisses it by regularly criticising States parties - that are middle-income countries - for not providing non-nationals with sufficient access to economic rights (i.e. work rights), compared to nationals. ${ }^{80}$ For instance, the Committee expressed concerns about

76 The CESCR expressed concerns and recommendations regarding States parties' protection of non-nationals' ESC rights in 133 Concluding Observations, out of the 158 issued between 2008 and 2018 .

77 The CESCR refers to Article 2(2) to criticise States for discriminating against non-nationals in 56 Concluding Observations, out of the 133 in which it expresses concerns in that regard between 2008 and 2018 .

78 ICESCR, Preamble.

79 The word 'immediate' is used five times and the words 'core obligation' are used two times in the Concluding Observations issued by the CESCR from 2008 to 2018 in relation to nonnationals' ESC rights, but they are not linked to the principle of non-discrimination.

8o See footnote 76: 'The CESCR expresses concerns and recommendations regarding States parties' protection of non-nationals' ESC rights in 133 Concluding Observations, out of the 158 issued between 2008 and 2018.' These Concluding Observations regularly discuss nonnationals' work rights, regardless of States' levels of income. 
the high rate of unemployment amongst migrants, asylum-seekers and refugees in Mexico in 2018. ${ }^{81}$ It also criticised the absence of a right to employment for refugees in Sri Lanka in 2017, ${ }^{82}$ and denounced poor working conditions of migrant workers in Urugay that same year. ${ }^{83}$ Furthermore, the Committee does not limit its comments to expressions of concerns. It expects that States parties to the ICESCR adopt practical measures to ensure similar protection of work rights between nationals and non-nationals. In its 2017 Concluding Observations on the Russian Federation, for example, the Committee requires that migrant workers 'enjoy the same [working] conditions as other workers' and that Russia initiates 'effective inspection mechanisms' as a result. ${ }^{84} \mathrm{How}$ ever, the Committee never justifies why Article 2(3) of the ICESCR is not applicable.

The Committee's failure to engage with clashes between Article 2(3) of the ICESCR and the universal scope of this treaty, as well as with the principle of non-discrimination, can have damaging effects. The absence of transparent legal reasoning to protect non-nationals' ESC rights creates legal uncertainty for duty-bearers and right-holders (which States can use as an excuse for not fulfilling their obligations), and impedes the legitimacy of the Committee as a quasi-judicial body. Therefore, further transparency would allow the CESCR to protect non-nationals' ESC rights more sustainably in the face of the COVID-19 pandemic.

Protection of Non-nationals' Economic, Social and Cultural Rights by the Committee on the Rights of Migrant Workers (cMW)

3.2.1 Extensive Protection of Non-nationals' Economic Social and Cultural Rights in General Comments

This section examines how the CMW (thereafter called 'the Committee' in this section) interprets ambiguities regarding the extent to which ESC rights apply to non-nationals in the ICMW. It considers how the Committee interprets migrant workers' ESC rights in its General Comments, since these have a quasiauthoritative status in international human rights law. So far, the Committee has only issued four General Comments but all of them recognise that States

81 CESCR, 'Concluding observations on the combined fifth and sixth periodic reports of Mexico' (17 April 2018) Un Doc. E/C.12/MEX/Co/5-6, para 24.

82 CESCR, 'Concluding observations on the fifth periodic report of Sri Lanka' (4 August 2017) UN Doc. E/C.12/LKA/CO/5, para 19.

83 CESCR, 'Concluding observations on the fifth periodic report of Uruguay' (20 July 2017) UN Doc. E/C.12/URY/Co/5, paras 26-27.

84 CESCR, 'Concluding observations on the sixth periodic report of the Russian Federation' (16 October 2017) UN Doc. E/C.12/RUs/Co/6, para 33. 
parties to the ICMW must fulfil migrant workers' ESC rights (and often, on an equal basis than nationals).

The right to work and trade union rights, ${ }^{85}$ as well as the right to access social security, ${ }^{86}$ health services, ${ }^{87}$ and education, ${ }^{88}$ are discussed in great details in General Comments 1, 2 and 4, by referring to the relevant ESC rights provisions enshrined in the ICMW. Furthermore, the Committee often reiterates the principle of equality of treatment with nationals when outlining what these rights entail. In General Comments 1, 2 and 4, it emphasises that all migrant workers should access labour law protection, social security benefits and emergency healthcare on the same basis as nationals (as required by the ICMW). ${ }^{89}$ It also stresses that their children should be protected from economic exploitation and that they should access an adequate standard of living, healthcare, education and professional training, on a similar standing as nationals (as required by the ICMW ). ${ }^{90}$ However, these statements merely reiterate rights and principles that are already recognised in the ICMW.

Some General Comments, nonetheless, extends the Committee's protection of non-nationals' ESC rights beyond the text of the ICMW, by declaring that States that are parties to both the ICMW and the ICESCR have broader

85 CMW, 'General Comment No. 1 on Migrant Domestic Workers' (23 February 2011) UN Doc. CMW/C/GC/1, paras 37-41, 45-47; CMW, 'General Comment No. 2 on the Rights of Migrant Workers in an Irregular Situation and Members of Their Families' (28 August 2013) UN Doc. $\mathrm{CMW} / \mathrm{C} / \mathrm{GC} / 2$, paras 6o-66. (See also in the context of children's right to protection from economic exploitation: CMW and Committee on the Rights of the Child, '(Joint) General Comment No. 4 on State Obligations Regarding the Human Rights of Children in the Context of International Migration in Countries of Origin, Transit, Destination and Return' (16 November 2017) UN Doc. CMW/C/GC/4-CRC/C/GC/23, paras 45-48).

86 CMW, 'General Comment 1', (n 85), paras 42-44; CMW, 'General Comment 2', (n 85), paras 67-71; CMW, Joint General Comment 4, (n 85), para 47.

87 CMW, 'General Comment 1', (n 85), paras 42-44; CMW, 'General Comment 2', (n 85), paras 72-74; CMW, 'Joint General Comment 4', (n 85), paras 54-58.

88 CMW, 'General Comment 1', (n 85), paras 57 and 59; CMW, 'General Comment 2', (n 85), paras 75-79; CMW, 'Joint General Comment 4', (n 85), paras 59-63.

89 смw, 'General Comment 1', (n 85), paras 38, 42, 57; cmw, 'General Comment 2', (n 85), paras $62,63,64,67,69,72,73,75,76$; CMW and Committee on the Rights of the Child, '(Joint) General Comment No. 3 of the Committee on the Protection of the Rights of All Migrant Workers and Members of Their Families and No. 22 of the Committee on the Rights of the Child on the General Principles Regarding the Human Rights of Children in the Context of International Migration', paras 22, 25 (in general terms); CMW, 'Joint General Comment 4', (n 85), paras 45, 47, 55, 59, 62.

90 CMw, 'General Comment 1' (n 85), paras 38, 42, 57; cmw, 'General Comment 2', (n 85), paras 62, 63, 64, 67, 69, 72, 73, 75, 76; CMW and Committee on the Rights of the Child, (n 89), paras 22, 25 (in general terms); CMW 'Joint General Comment 4', (n 85), paras 45, $47,55,59,62$. 
obligations regarding those rights. For instance, while General Comment 1 on 'Migrant Domestic Workers' acknowledges that Article 43(1)(e) of the ICMW only entitles documented migrant workers to access social and health services on the same basis as nationals, it reminds States parties of their (broader) obligations under the ICESCR. ${ }^{91}$ It declares that the ICESCR requires that States guarantee the highest attainable standard of health to 'all persons within their jurisdiction, irrespective of their immigration status', i.e. including undocumented migrant workers. ${ }^{92}$

In General Comment 2 on 'Migrant Workers in an Irregular Situation', the Committee regularly refers to the ICESCR to interpret more extensively the provisions set in the ICMW. ${ }^{93}$ It justifies this approach by affirming that nothing should prevent States parties to the ICMW from granting more favourable rights to migrant workers, since other UN human rights treaties in force prohibit discrimination based on immigration status. ${ }^{94}$ The CMW then explicitly recognises that the ICESCR protects more ESC rights than the ICMW, that these rights have a broader scope and that they are not restricted to documented migrant workers (as it is often the case under the ICMW) $\cdot{ }^{95}$ As a result, the Committee interprets the right to health, the right to education and trade union rights extensively for States parties to both the ICMW and the ICESCR. For instance, the Committee declares that Article 28 of the ICMW, restricting the right to health to urgent medical care for undocumented migrants, should be read together with Article 12 of the ICESCR, which 'create broader obligations for States parties to both instruments. ${ }^{96}$ Therefore, the Committee recognises that States parties to the ICMW and to the ICESCR must provide undocumented migrants with emergency healthcare (as per Article 28 ICMW), as well as primary, preventive, curative and palliative healthcare (as per Article 12 ICESCR). This interpretation is crucial in the COVID-19 context, as undocumented migrant often do not have access to testing and treatment or do not access them by fear of detention and deportation. ${ }^{97}$

Nevertheless, these General Comments do not clarify which standards the CMW expects States to comply with in practice. This is because this treaty body is mandated to monitor the implementation of the ICMW, and not the ICESCR. In addition, it fails to take a clear stand on how the ICESCR and the ICMW

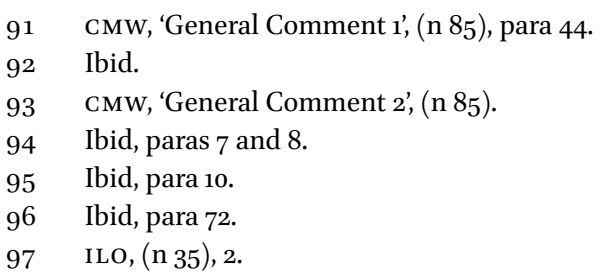


should interact, by considering those treaties both 'separate and freestanding', as well as 'complementary and mutually reinforcing' in General Comment 2, which is confusing. ${ }^{98}$ In a Joint Guidance Note on the Impacts of the COVID-19 Pandemic on the Human Rights of Migrants, the CMw highlights the importance of protecting migrant workers' access to health, social services, labour rights and education. ${ }^{99}$ However, again, it does not specify to which extent.

Ad hoc Protection of Non-nationals' Economic, Social and Cultural Rights in Concluding Observations

This section analyses the 58 Concluding Observations issued by the CMW during the decade that followed the 2008 economic crisis. This sheds further light on the extent to which the Committee expects States to realise the ESC rights of migrant workers in times of global austerity and therefore, how it may protect non-nationals' ESC rights during the COVID-19 crisis. This study of the Committee's reporting procedure highlights four key findings.

Firstly, the data analysed shows that the Committee regularly reviews States' compliance with rights to education, health, housing, social security and work. Therefore, the ESC rights provisions of the ICMW are not merely theoretical: their implementation is monitored in practice. Interestingly, a search based on the terminology used by the Committee in relation to ESC rights, highlights that the Committee monitors some fields more than others in its Concluding Observations. The field of work clearly takes prevalence, with the word 'work' appearing more than 1,30o times (and trade unions, 60 times). This is not surprising considering the focus of the ICMW, i.e., migrant workers, and its subsequent emphasis on work-related rights. The Committee, nonetheless, often monitors health issues (the words 'health' and 'medical' appear more than 160 times); education ('education' and 'school' appear 130 times); social security (those words appear approximately 60 times); and finally, more rarely, housing (16 times). These slight disparities cannot be explained by the text of the ICMW itself, given the latter focuses equally on all these areas. Nevertheless, the right to housing should be taken more seriously given the number of migrant workers living in crowded and unsanitary accommodations (a key driver in COVID-19 transmissions). ${ }^{100}$

Secondly, the data studied for this paper demonstrates that the Committee strongly upholds the principle of non-discrimination in its reporting

98 CMW, 'General Comment 2', (n 85), para 7.

99 CMW, 'Joint Guidance Note on Covid-19', (n 4), recommendations 2, 3, 4 and 6.

100 UN Secretary-General, Covid-19 and Human Rights: We Are All in This Together (2020) <https://www.un.org/sites/un2.un.org/files/un_policy_brief_on_human_rights_and_covid_23_april_2020.pdf> accessed 9 September 2020, 11. 
procedure, to protect migrant workers' ESC rights. During the $2008-2018$ decade of austerity, the Committee highlighted multiple instances of discrimination in the context of ESC rights, urging States to remedy such situations in its Concluding Observations. It explicitly refers to the word 'discrimination' in more than half of its Concluding Observations when discussing issues such as work, health, education, housing, social security, or social stigmatisation. Moreover, without necessarily employing the word 'discrimination', the Committee systematically expresses concern over migrant workers' reduced access to ESC rights and regularly explains their vulnerability in this regard (e.g. fear of being deported, absence of papers, qualifications not recognised, racism, policies reserved to nationals etc.). For instance, in its 2018 Concluding Observations on Algeria, the Committee highlights that migrant workers - in particular those in an irregular situation - are more vulnerable to violations of their right to work, health, education and housing than the rest of the population. ${ }^{101}$ It explicitly links those issues to: the lack of prosecution of employers practicing forced labour; migrant workers' fear of being arrested when seeking medical assistance; the need to present a residence certificate to enrol children in schools or to the fact that social housing is reserved to nationals. ${ }^{102}$

Thirdly, the data examined in this article highlights that the Committee frequently monitors the application of the principle of equality of treatment with nationals when reviewing migrant workers' ESC rights. In more than half of its Concluding Observations issued between 2008 and 2018, the Committee reminds States of their obligation to treat migrant workers on the same basis as nationals in various fields of ESC rights (using words such as 'nationals', 'citizens' or 'equality'). The Committee clearly expects that States fulfil this requirement across a wide array of ESC rights, by taking note of positive steps made towards this goal or by expressing concern about unsatisfactory measures or outcomes. For instance, in its 2018 Concluding Observations on Mozambique, the Committee monitored the application of the principle of equality of treatment between nationals and migrant workers when reviewing areas of labour law, remuneration, labour inspections, social security and healthcare. ${ }^{103}$ However, the Committee never seems to allow differential treatments based on citizenship (yet, implicitly accepted in the ICMW) and therefore, does not clarify this concept.

\footnotetext{
101 CMW, 'Concluding observations on the second periodic report of Algeria' (25 May 2018) UN Doc. CMW/C/DZA/Co/2, paras 33, 45, 47, 51, 53 .

102 Ibid.

$103 \mathrm{CMW}$, 'Concluding observations on the initial report of Mozambique' (16 October 2018) UN Doc. CMW/C/MOz/Co/1, paras 27, 40(a), 41-42(b), 44(a).
} 
Lastly, this decade of Concluding Observations highlights that the Committee consistently expects States parties to the ICMW to provide a high degree of protection to undocumented migrants' ESC rights. Every time the Committee mentions undocumented migrants (i.e. in more than half of its Concluding Observations), it is to express concern over their reduced access to ESC rights. Moreover, the Committee sometimes dismisses the restrictive wording of the ICMW to further protect these rights. For instance, in its 2017 Concluding Observations on Ecuador, the Committee ignores the requirements set by Article 28 ICMW, which limits undocumented migrants' right to health to emergency healthcare. Instead, it requires that Ecuador provides all migrant workers and their families - 'regardless of nationality and immigration status' - with the right to the highest standard of health attainable as enshrined in Article 12 of the ICESCR, and declares that this right should not be limited to emergency care. ${ }^{104}$ It also urges Ecuador to comply with the principle of non-discrimination by referring to General Comment No. 14 on the right to health, drafted by the CESCR. ${ }^{105}$ Nevertheless, the CMW does not justify its reasoning by specifying that Ecuador is party to the ICESCR (which the CMW would not be mandated to monitor anyway).

Therefore, the Committee answers questions left open by its General Comment 2 on 'Migrant Workers in an Irregular Situation', by prioritising the application of more generous provisions enshrined in the ICESCR, over restrictive ESC rights provisions enshrined in the ICM W. The Committee, nonetheless, fails to clearly explain its reasoning, thereby leaving legal uncertainty around the interpretation and application of the ICMW and damaging its legitimacy as a quasi-judicial body.

The purpose of this article being to assess to what extent UN human rights treaties can contribute to protecting non-nationals' ESC rights, especially during a crisis such as the COVID-19 pandemic, this third section analysed how relevant UN treaty bodies interpreted restrictive treaty provisions during a recent crisis: the 2008-2018 decade of austerity. It concluded that the CESCR and the CMW protect non-nationals' ESC rights extensively in their General Comments and in their Concluding Observations. Both Committees do so by frequently referring to the principle of non-discrimination, the importance of ESC rights in human rights law, and the vulnerability of non-nationals to violations of these rights. However, the CESCR and the CMW do not sufficiently

\footnotetext{
104 CMW, 'Concluding observations on the third periodic report of Ecuador' (5 October 2017) $\mathrm{CMW} / \mathrm{C} / \mathrm{ECU} / \mathrm{CO} / 3$, paras $32-33$.

105 Ibid.
} 
justify why they disregard problematic treaty provisions that conflict with the essence of the ICESCR and the ICMW, or with the legal system in which they operate. This lack of rationale can damage the credibility of UN treaty bodies as quasi-judicial, transparent and accountable institutions, and perpetuates the legal uncertainty surrounding the protection of non-nationals' ESC rights. As a result, this article proceeds to explore sustainable solutions enabling the CESCR and the CMW to bridge these gaps, by adequately justifying their protection of non-nationals' ESC rights in the COVID-19 context.

\section{4}

Justifying the Protection of Non-nationals' Economic, Social and Cultural Rights by un Treaty Bodies

As the COVID-19 crisis exacerbates pre-existing inequalities such as nonnationals' reduced access to health, education, work and social assistance, already heightened by a decade of global austerity, this article examines to what extent UN human rights treaties can further protect non-nationals' ESC rights. It highlighted that key treaties such as the ICESCR and the ICMW contained restrictive provisions regarding non-nationals' ESC rights, that were either conflicting with the essence of the treaty or with more protective UN human rights treaties. It then demonstrated that UN treaty bodies such as the CESCR and the CMW dismissed these restrictive provisions to further protect non-nationals' ESC rights when interpreting the ICESCR and the ICMW, but that their lack of rationale damaged their credibility and perpetuated legal uncertainty. This section therefore explores what legal reasoning the CESCR and the CMW may wish to demonstrate when faced with restrictive treaty provisions, in order to provide more sustainable legal solutions in the midst of the Covid-19 crisis. It suggests that these UN treaty bodies continue to protect extensively nonnationals' ESC rights, but by explicitly declaring differential treatments based on citizenship unlawful, and by relying on rules of treaty interpretation as well as on the recommendations of the Fragmentation Report.

\subsection{Declaring Differential Treatments Based on Citizenship Impermissible}

The first ambiguity apparent in the UN human rights treaties studied in this article is the allowance of differential treatments based on citizenship. This article suggests that the CESCR and the CMW declare such treatments impermissible, by upholding the principle of non-discrimination and by applying the test of proportionality. 


\subsubsection{Upholding the Principle of Non-discrimination}

As discussed in section 2 above, the universal scope of international human rights law is reflected in the drafting history and preambles of its treaties. Their universal scope, altogether with the inclusion of non-discrimination clauses in all UN (and regional) human rights treaties, ${ }^{106}$ elevate the prohibition of discrimination as one of the cornerstones of the discipline. This is confirmed by the importance the CESCR and the CMW give to this concept, when discussing non-nationals' ESC rights. The General Comments and Concluding Observations studied in section 3 consistently refer to (and monitor) States' prohibition to discriminate non-nationals. The CESCR even recognises that this prohibition represents a 'minimum core obligation' of the ICESCR ${ }^{107}$ i.e. the 'raison d'etre' of this treaty, capable of setting minimum levels of ESC rights protection which must be fulfilled in all circumstances. ${ }^{108}$ Therefore, the overwhelming importance of the prohibition of discrimination in international human rights law should leave little room for the 'random' allowance of differential treatments based on citizenship by few UN human rights treaties, which include the ICESCR and the ICMW. This, alone, should encourage the CESCR and the CMW to dismiss explicitly the relevance of such allowances when interpreting problematic treaty provisions in their General Comments and in their monitoring procedures.

However, the 'minimum core obligation to not discriminate' does not yet represent a strong legal concept capable of declaring differential treatments based on citizenship, impermissible. The CESCR uses this terminology inconsistently: the words 'minimum core' do not appear in General Comment 20 on 'Non-discrimination in ESC rights', ${ }^{109}$ and appear only twice in the Concluding Observations studied in this paper, regarding non-nationals. ${ }^{110}$ Furthermore,

106 See footnote 18 , listing all the non-discrimination clauses found in the UDHR and in UN human rights treaties; as well as in key UN treaties on non-nationals, and in regional treaties protecting ESC rights.

107 E.g. Cescr, 'General Comment 13', (n 68), para 57; CESCR, 'General Comment 14', (n 68), para $43(\mathrm{a})$.

108 CESCR, 'General Comment 3', (n 66), para 10.

109 CESCR, 'General Comment 20', (n 66).

110 CESCR, 'Concluding Observations on the fifth periodic report of Spain' (6 June 2012) UN Doc. E/C.12/ESP/CO/5, para 8: "The Committee expresses concern that the levels of effective protection for the rights enshrined in the Covenant have been reduced as a result of the austerity measures adopted by the State party, which disproportionately curtail the enjoyment of their rights by (...) migrants and asylum seekers (art. 2, para. 1). The Committee recommends that the State party ensure that all the austerity measures adopted reflect the minimum core content of all the Covenant rights and that it take all appropriate measures to protect that core content under any circumstances, especially for 
the CESCR fails to clarify whether States are allowed to derogate from 'minimum core' obligations such as the prohibition to discriminate. The 25 General Comments issued to date are either silent on this issue or set contradictory standards, since some recognise that minimum core obligations must be fulfilled in all circumstances, ${ }^{111}$ while others allow exceptions. ${ }^{112}$

As for the CMW, it never refers to 'minimum core' obligations in any of its General Comments or in any of the Concluding Observations studied in this article, in the context of ESC rights. The lack of an assertive and principled protection of the principle of non-discrimination by UN treaty bodies, nonetheless, can result in tolerating differential treatments based on citizenship. For instance, in General Comment 20, the CESCR allows States to reduce nonnationals' access to ESC rights as long as they justify that they have made every effort possible to use all resources at their disposition and tried to prioritise compliance with the obligation to not discriminate. ${ }^{13}$ It is, therefore, regrettable that the CESCR and the CMW failed to clarify or even mention this concept in recent CoviD-19 Statements. ${ }^{114}$

\subsubsection{Applying the Test of Proportionality}

Since a 'minimum core obligation to not discriminate' does not yet represent a strong legal concept capable of declaring differential treatments based on citizenship impermissible, the CESCR and the CMW need to consider other legal avenues. They could do so by assessing the legality of such treatments through

disadvantaged and marginalized individuals and groups'. CESCR, 'Concluding Observations on the combined fourth and fifth periodic reports of the Kingdom of the Netherlands' (9 December 2010) UN Doc. E/C.12/NDL/CO/4-5, para 25: 'The Committee urges the State party to $(. .).[\mathrm{m}]$ eet its core obligations under the Covenant and ensure that the minimum essential level relating to the right to housing, health and education is respected, protected and fulfilled in relation to undocumented migrants.'

111 E.g. CESCR, 'General Comment 14', (n 68), para 47: 'a State party cannot, under any circumstances whatsoever, justify its non-compliance with the core obligations set out in paragraph 43 above, which are non-derogable'.

112 E.g. CESCR, 'General Comment 3', (n 66), para 10: 'In order for a State party to be able to attribute its failure to meet at least its minimum core obligations to a lack of available resources it must demonstrate that every effort has been made to use all resources that are at its disposition in an effort to satisfy, as a matter of priority, those minimum obligations'.

113 CESCR, 'General Comment No. 20', (n 66), para 13: 'A failure to remove differential treatment on the basis of a lack of available resources is not an objective and reasonable justification unless every effort has been made to use all resources that are at the State party's disposition in an effort to address and eliminate the discrimination, as a matter of priority.'

114 CESCR, 'Statement on COVID-19', (n 75), para 12: 'the minimum core obligations imposed by the Covenant should be prioritized'; cmw, 'Joint Guidance Note on Covid-19', (n 4). 
a test similar to the proportionality test used by the European Court of Human Rights, as suggested in their General Comments. ${ }^{115}$ General Comment 20 of the CESCR on 'Non-discrimination in ESC rights' considers that differential treatments based on citizenship may be allowed, if States pursue legitimate aims and if these treatments are proportionate to the aims pursued. ${ }^{116}$ General Comment 2 of the CMW on 'Migrant Workers in an Irregular Situation' also identifies the need to apply such a test to ensure that differential treatments based on citizenship do not constitute discrimination. ${ }^{117}$ Similarly, its Joint Guidance Note on the Impacts of the Covid-19 Pandemic on the Human Rights of Migrants declares that

'State emergency responses to the CoviD-19 pandemic [must] be necessary to achieve legitimate public health goals; proportionately apply the least intrusive means; and be non-discriminatory so as not to be used to target particularly vulnerable groups' ${ }^{\prime 18}$

Furthermore, as the world is undergoing another recession, States may further attempt to justify differential treatments based on citizenship by the need to reduce budgets or to increase employment rates, advocating for long-term and wide-scale benefits. States may portray aggressive migration policies reducing non-nationals' access to ESC rights as a way to reduce social welfare, health, housing or education budgets; or as a way to prioritise nationals seeking employment. However, evidence does not highlight that restricting non-nationals' ESC rights enables States to meet these objectives and represents an adequate immigration control strategy, for three reasons. Firstly, the assumption that migrants will incur an economic loss to sovereign States is not accurate. Various reports highlight, on the contrary, that migrant workers make net contributions to public finances in both countries of origin and destination. ${ }^{119}$ They

115 See the vast case law developed under the Convention for the Protection of Human Rights and Fundamental Freedoms (as amended) 1950, ETs No. 005, Articles 8-11; Steven Greer, The Exceptions to Articles 8 to 11 of the European Convention on Human Rights (Human Rights Files No. 15) (Council of Europe, 1997) <https://www.echr.coe.int/LibraryDocs/ DG2/HRFILES/DG2-EN-HRFILES-15(1997).pdf> accessed 9 September 2020, 9-17.

116 CESCR, 'General Comment 2o', (n 66), para 13.

117 CMW, 'General Comment 2', (n 85), para 18.

118 CMW, 'Joint Guidance Note on Covid-19', (n 4), 2.

119 International Organization for Migration, World Migration Report 2020 (2019) <https:// www.un.org/sites/un2.un.org/files/wmr_2020.pdf> accessed 9 September 2020, ch 5: 'Reflections on migrants' contributions in an era of increasing disruption and disinformation'. See the example of the U K: Oxford Economics, The Fiscal Impact of Immigration on the UK: A Report for the Migration Advisory Committee (2018) <https://assets.publishing. 
also directly contribute to systems crucial to realise EsC rights such as health, education or social assistance. For instance, non-nationals are fundamental to the very existence of the UK's National Health System, considering they represent at least $20 \%$ of its employees (key in the fight against coviD-19). ${ }^{120}$

Secondly, the assumption that restricting non-nationals' ESC rights will deter migration is not inaccurate. De Haas and al. argue that the effects of welfare policies on migration flux are ambiguous and that the real drivers behind migration flux are job opportunities. ${ }^{121}$ Research, nevertheless, evidences that limiting non-nationals' access to ESC rights can be harmful in other ways. For instance, restricting non-nationals' access to health to emergency care can increase the healthcare costs of this population, since it is more expensive to treat preventable conditions through emergency care than through primary care. ${ }^{122}$

Thirdly and more importantly, one should not use direct economic losses as a reason for not realising ESC rights. On one hand, investing in the realisation of ESC rights for all can be economically positive. For instance, providing wider access to healthcare to non-nationals can contribute to creating healthier and more productive populations, and result in lower health expenditures. ${ }^{123} \mathrm{On}$ the other hand, investing in non-nationals' ESC rights based on the economic gains or losses this represents, fails to recognise that these rights are essential to human dignity and legally binding upon States. As contended by Weiler, considering individuals in utilitarian terms and protecting them depending on their nationality, undervalues their common humanity and is undesirable in human rights law. ${ }^{124}$

As a result, if the CESCR and the CMW were to assess the lawfulness of differential treatments based on citizenship in the context of the Covid-19 crisis

service.gov.uk/government/uploads/system/uploads/attachment_data/file/759376/The _ Fiscal_Impact_of_Immigration_on_the_UK.pdf> accessed 9 September 2020, 6: 'Over their lifecycle, we found that EEA and non-EEA migrants from the 2016 cohort make a net positive contribution of $£_{19.3}$ billion and $£_{7.5}$ billion respectively'.

120 The King's Fund, What do we know about the impact of immigration on the NHS? (2015) <http://www.kingsfund.org.uk/projects/verdict/what-do-we-know-about-impact-immigration-nhs $>$ accessed 9 September 2020.

121 H de Haas et al., 'International Migration: Trends, Determinants, and Policy Effects' (2019) 45 Population and Development Review $885,898$.

122 B Gray and E van Ginneken, 'Health Care for Undocumented Migrants: European Approaches' (2012) 33 Issue Brief (Commonwealth Fund) 1.

123 P Illingworth and wE Parmet, 'The Right to Health: Why It Should Apply to Immigrants' (2015) 8 Public Health Ethics 14.

124 J Weiler, "Thou Shalt Not Oppress a Stranger: On the Judicial Protection of the Human Rights of Non-EC Nationals - A Critique' (1992) 3 European Journal of International Law $65,65^{-69}$. 
by applying a test of proportionality, ${ }^{125}$ they would find such treatments unlawful. They may recognise that a State's law prescribes austerity measures restricting non-nationals' ESC rights (the first step of the test of proportionality). However, they are unlikely to hold that undertaking such measures to control immigration is a legitimate aim (the second step of this test). These UN treaty bodies, nonetheless, should explicitly justify their assessment by highlighting non-nationals' contributions to national economies, the lack of evidence supporting the efficiency of such measures, and the absence of rights-based approach in these arguments. This would strengthen their standing as quasijudicial, transparent and accountable institutions, and combat the legal uncertainty surrounding non-nationals' ESC rights.

\subsection{Applying Rules of Treaties Interpretation to Clarify the Protection of Non-nationals' Economic, Social and Cultural Rights}

The ambiguity surrounding the protection of non-nationals' ESC rights emanates from the provisions of UN human rights treaties themselves. These include: Article 2(3) of the ICESCR, which allows 'developing countries' to determine to what extent they wish to protect the economic rights of non-nationals but clash with the essence of this treaty; and the EsC rights provisions of the ICMW, which provide less protection than the ICESCR, especially for undocumented migrants. It is suggested that UN treaty bodies apply the rules of treaty interpretation laid out in the VCLT to decide on the applicability of such conflicting provisions.

Whilst Linderfalk criticises the VCLT for the flexibility of its rules on treaty interpretation, ${ }^{126}$ it remains the key reference for such an exercise (including for human rights treaties, though some scholars call for specialised techniques of interpretation instead). ${ }^{127}$ Its Article 31 stresses that, as a general rule,

125 See Cescr, 'General Comment 2o', (n 66), para 13; and cmw, 'General Comment 2', (n 85), para 18.

126 U Linderfalk, 'Is Treaty Interpretation an Art or a Science? International Law and Rational Decision Making' (2015) 26 European Journal of International Law 169; see also J Tobin, 'Seeking to Persuade: A Constructive Approach to Human Rights Treaty Interpretation' (2010) 23 Harvard Human Rights Journal 1.

127 Gardiner,(n 26). See discussion on the application of the VCLT to human rights treaties: $\mathrm{J}$ Crawford and A Keene, 'Interpretation of the human rights treaties by the International Court of Justice' (2020) 24 International Journal of Human Rights 935; M Craven, 'Legal Differentiation and the Concept of the Human Rights Treaty in International Law' (2000) 11 European Journal of International Law 489; G Letsas, 'Strasbourg's Interpretive Ethic: Lessons for the International Lawyer' (2010) 21 European Journal of International Law 509; В Çali, 'Specialized Rules of Treaty Interpretation: Human Rights', in р в Hollis, The Oxford Guide to Treaties (Oxford University Press, 2012), 525. 
treaties should be interpreted by examining three aspects. ${ }^{128}$ The first consists in studying the ordinary meaning of the terms of the treaty, i.e. the text of the treaty, including its preamble and annexes. ${ }^{129}$ The second consists in analysing its context, i.e. agreements or instruments connected to the treaty and accepted by its States parties, which represent the legal framework in which it operates. ${ }^{130}$ Finally, the third aspect consists in examining the object and purpose of the treaty, i.e. the objectives the treaty was trying to achieve when it entered into force. ${ }^{131}$

Article 32 then specifies that if the meaning of the treaty remains unclear or illogical after having applied the general rule set in Article 31, one should use supplementary means of interpretation, such as the study of the Travaux Préparatoires and the circumstances in which the treaty was concluded..$^{132}$ However, Article 31 of the VCLT does not indicate which aspect of the treaty should be studied first. As highlighted by Jonas and Saunders, the objective, subjective and teleological schools tend to see differently which of those elements take precedence in treaty interpretation. ${ }^{133}$ While the purpose of this article is not to discuss in depth each of these schools, what follows highlights that the CESCR and even more the CMW are less likely to sufficiently protect non-nationals' ESC rights by solely following the objective school of treaty interpretation. If the CESCR was to interpret Article 2(3) of the ICESCR by studying the three aspects listed by Article 31 of the VCLT, it would read Article 2(3) as protecting non-nationals' ESC rights for several reasons.

Firstly, the ordinary meaning of the text of Article 2(3) of the ICESCR highlights the protection of non-nationals' EsC rights. As noted above, the text of Article 2(3) permits exceptionally 'developing countries' to determine to what extent they would guarantee the 'economic rights' recognised in the ICESCR to non-nationals, but not social or cultural rights. ${ }^{134}$ Furthermore, an interpretation of Article 2(3) as permitting discriminatory treatment against nonnationals in the enjoyment of ESC rights would be inconsistent with the text of Article 2(2), which explicitly prohibits States from discriminating against

\footnotetext{
128 VCLT, Article 31.

129 Ibid, Article 31(1) and (2).

130 Ibid, Article 31(1), (2) and (3).

131 Ibid, Article 31(1).

132 Ibid, Article 32.

133 DS Jonas and TN Saunders, 'The Object and Purpose of a Treaty: Three Interpretive Methods' (2010) 43 Vanderbilt Journal of Transnational Law 565, 577-578.

134 ICESCR, Article 2(3).
} 
individuals because of their national origin, and with the fact that ESC rights listed in Articles 6-15 apply to 'everyone'. ${ }^{35}$

Secondly, the legal context in which the ICESCR operates does not support a reading of its Article 2(3) as permitting discrimination against non-nationals in the enjoyment of ESC rights. The Optional Protocol to the ICESCR and all UN human rights treaties ratified by States parties to the ICESCR, also embrace its universal scope and prohibit States from discriminating against vulnerable groups such as non-nationals. ${ }^{136}$

Thirdly, the object and purpose of the ICESCR, which Gardiner would connect to its Preamble given it embraces the treaty's aims and objectives, ${ }^{137}$ highlights that the ICESCR intends to protect everyone's ESC rights, thereby including non-nationals. ${ }^{138}$

Finally, if the CESCR were to recourse to the Travaux Préparatoires of the ICESCR to clarify the outcome of the general rule of interpretation set by Article $3^{1}$ of the VCLT (as recommended by Article 32), it would confirm the irrelevance of Article 2(3) of the ICESCR to the COVID-19 pandemic. As argued by Dankwa, the drafting of Article 2(3) of the ICESCR results from the desire of countries who had recently became independent from colonialism, to protect their economies from powerful nationals of former colonial States. ${ }^{139}$ The VCLT rules of treaty interpretation support the CESCR, in its attempts to protect non-nationals' ESC rights despite the wording of Article 2(3) of the ICESCR.

If the CMW were to interpret the restrictive ESC rights provisions of the ICMW by applying the rules of treaty interpretation in Article 31 of the VCLT, its protection of migrant workers' ESC rights would vary depending on which method it prioritises. First, studying the ordinary meaning of the text of the ICMW results in lack of clarity. Words such as 'everyone' do not appear in the preamble or the provisions of the ICMW, since this treaty focuses on migrant workers. Provisions of the ICMW, nonetheless, entitle documented migrant workers to the same ESC rights as nationals, but only entitle undocumented

135 Ibid, Articles 2(2) and 6-15.

136 Optional Protocol to the ICESCR, (n 64), Preamble. See $\mathrm{n} 18$ for the full references of the following treaties: ICERD, Preamble and Article 1; ICCPR, Preamble and Article 2(1); CEDAW, Preamble and Article 1; CAT, Preamble and Article 1(1); CRC, Preamble and Article 2(1); ICMW, Preamble and Article 7; CRPD, Preamble and Article 4(1); ICP PED, Preamble.

137 Gardiner, (n 26), 205-206.

138 ICESCR, Preamble.

139 Dankwa, (n 36), 231-236; UnGA, 'Draft International Covenants on Human Rights, Report of the Third Committee' (1962) UN Doc. A/5365, para 65-70 (see para 69: 'Far from opening the door to discrimination, the amendments were designed to restore the proper balance by enabling nationals to exercise their rights'). 
migrants with minimal services (e.g. 'emergency medical care'). ${ }^{140}$ The text of Article 7 may encourage the CMW to expect similar levels of ESC rights protection between documented and undocumented migrants, since it explicitly prohibits discrimination based on 'other status' (thereby, including migration status) amongst migrant workers. ${ }^{141}$ However, it is unclear how the CMW should interpret the scope of migrant workers' ESC rights, based solely on the text of this treaty.

Second, examining the legal context in which the ICMW operates supports the protection of non-nationals' ESC rights. While the ICMW has no Optional Protocol, all Un human rights treaties ratified by States parties to the ICMW have a universal scope and prohibit States from discriminating against vulnerable groups, such as non-nationals. ${ }^{142}$ However, the third aspect of the general rule of treaty interpretation, i.e. analysing its object and purpose, does not clarify to what extent States parties ought to protect migrant workers' ESC rights, compared to nationals. The Preamble of the ICMW, which Gardiner would link to its object and purpose, ${ }^{143}$ recognises the vulnerability of migrant workers and the importance of protecting their rights, including ESC rights. ${ }^{144}$ Nevertheless, it does not specify to what extent, compared to nationals. Since the CMW cannot reach a clear outcome after having applied Article 31 of the VCLT, it could study the Travaux Préparatoires of the ICMW and the circumstances of its conclusion, as per Article 32 of the VCLT. ${ }^{145}$ The drafting of the ICMW results from significant consensus between 'receiving States' and 'sending States', regarding the protection of migrant workers' rights. ${ }^{146}$ According to Lönnroth, the drafters of the ICMW intended to provide a broad set of rights for everyone, ${ }^{147}$ but the second reading of the text shifted the balance towards

\footnotetext{
140 ICMW, Articles 45(1)(c) and 28.

141 Ibid, Article 7.

142 See footnote 18 for the full references of the following treaties: ICERD, Preamble and Article 1; ICCPR, Preamble and Article 2(1); ICESCR, Preamble and Article 2(2); CEDAW, Preamble and Article 1; CAT, Preamble and Article 1(1); CRC, Preamble and Article 2(1); ICMW, Preamble and Article 7; CRPD, Preamble and Article 4(1); ICPPED, Preamble.

143 Gardiner, (n 26), 205-206.

144 ICMW, Preamble.

145 VCLT, Article 32.

146 LS Bosniak, 'Human Rights, State Sovereignty and the Protection of Undocumented Migrants under the International Migrant Workers Convention' (1991) 25 International Migration Review 737; J Lönnroth, 'The International Convention on the Rights of All Migrant Workers and Members of Their Families in the Context of International Migration Policies: An Analysis of Ten Years of Negotiation' (1991) 25 International Migration Review 710; Hune and Niessen (1991), (n 46); Hune and Niessen (1994), (n 59).

147 Lönnroth, (n 146), 711.
} 
States' interests rather than absolute rights. ${ }^{148}$ Therefore, analysing the text of the ICMW and its Travaux Préparatoires supports an interpretation restricting the scope of migrant workers' ESC rights. Nevertheless, the legal context of the ICMW, as well as its object and purpose, require that States provide further protection of ESC rights of migrant workers. It is, therefore, unclear how the CMW should interpret restrictive ESC rights provisions of the ICMW.

One could suggest that UN treaty bodies stress, and perhaps even prioritise, the object and purpose of the ICESCR and the ICMW (i.e. the teleological approach). The reason behind this argument is the significant weight given to this concept in the VCLT, which repeatedly emphasises States' obligation to not defeat the object and purpose of a treaty (before its entry into force, when expressing reservations, when interpreting it, when modifying it, when suspending it, and when fulfilling it). ${ }^{149}$ As discussed above, it seems that the object and purpose of treaties on human rights, such as the ICESCR and the ICMW, is to protect the human rights of everyone based on human dignity. The achievement of this goal is facilitated by the well-established prohibition of discrimination in UN human rights treaties, including on the ground of national origin.

This view was further developed by the European Committee of Social Rights (Council of Europe) in International Federation of Human Rights Leagues $(F I D H) v$ France, in the context of undocumented migrants' access to healthcare. ${ }^{150}$ In this decision, the European Committee of Social Rights disregarded the Appendix of the European Social Charter, which excludes certain non-nationals from the scope of this treaty, on the basis that this provision contradicted the object and purpose of this treaty (by reference to Article 31 of the VCLT ). ${ }^{151}$ While unorthodox in international law, this decision demonstrates that human rights bodies can adopt a more assertive legal rationale to protect non-nationals' ESC rights in order to avoid incoherent rulings.

Nevertheless, the absence of hierarchy among the rules of treaty interpretation laid out in Articles $3^{1}$ and 32 of the VCLT leaves discretion to the CESCR and the CMW to arbitrarily adopt a particular school of treaty interpretation to protect non-nationals' ESC rights. UN treaty bodies, nonetheless, should thrive for transparency and legitimacy, especially in the midst of a crisis such as the COVID-19 pandemic where the implementation of treaties protecting nonnationals' ESC rights are likely to experience pushbacks from States parties.

\footnotetext{
148 Ibid, $721-723$.

149 VCLT, Articles 18, 19(c), 20(2), 31(1), 33(4), 41(1), 58(1) and 6o(3).

150 European Committee of Social Rights, International Federation of Human Rights Leagues $($ FIDH ) v France (Merits) Complaint No. 14/2003 (3 November 2004).

$15^{1}$ Ibid, paras 26-32; European Social Charter, (n18), Appendix.
} 
As a result, this article suggests that $\mathrm{UN}$ treaty bodies integrate rules of international law allowing them to address conflicting treaty provisions more comprehensively than solely via the vCLT. This is particularly pertinent in international human rights law, where States' interests can result in incoherent treaty provisions, and where the increasing number of treaties can generate fragmentation and conflicts.

\subsection{Applying the ILC Fragmentation Report to Clarify the Protection of Non-nationals' Economic, Social and Cultural Rights}

This article suggests that UN treaty bodies justify their protection of nonnationals' ESC rights by referring to the Conclusions reached by the International Law Commission (ILC) in its 2006 Fragmentation Report. ${ }^{152}$ As discussed in section 2 , the application of the well-accepted maxims lex posterior and lex specialis (on how to interpret treaties dealing with the same subject) give prevalence to the ICMW over the ICESCR. While both treaties protect nonnationals' ESC rights (though the ICMW has more restrictive provisions), the ICMW was adopted more recently and enshrines norms specific to migrant workers. The principles lex specialis and lex posterior are, therefore, inadequate to address conflict of norms arising from the fragmentation of international human rights law and the increasing number of UN treaties, since they can reduce their scope of protection. ${ }^{153}$ This is particularly problematic during the COVID-19 pandemic, since it limits the ability of UN treaty bodies to protect non-nationals ESC rights, yet significantly jeopardised across the globe.

The Fragmentation Report mitigates the negative impact of this phenomenon through the doctrine of 'systemic integration'. ${ }^{154}$ This doctrine is grounded in Article 31(3) of the VCLT, which specifies that treaties must be interpreted in the light of the system to which they pertain (i.e. agreements, practices and relevant rules of international law) ${ }^{155}$ As a method of treaty interpretation, it was reaffirmed by the International Court of Justice in Legal Consequences for

152 UNGA Study Group of the International Law Commission, 'Fragmentation of International Law: Difficulties Arising from the Diversification and Expansion of International Law' (13 April 2006) UN Doc. A/CN.4/L.682 (UN Fragmentation Report); UNGA Study Group of the International Law Commission, 'Fragmentation of International Law: Difficulties Arising from the Diversification and Expansion of International Law' (18 July 2006) UN Doc. A/CN.4/L.702 (UN Summary Fragmentation Report).

153 A Lindroos, 'Addressing Norm Conflicts in a Fragmented Legal System: The Doctrine of Lex Specialis' (2005) 74 Nordic Journal of International Law 27. In this article, the author argues that the lex specialis principle is not suitable for all conflicts of norms, due to the fragmentation of the international legal system.

154 UN Fragmentation Report, (n 152), Section F.

155 VCLT, Article 31(1), (2), and (3). 
States of the Continued Presence of South Africa in Namibia. ${ }^{156}$ In this case, the Court declared that international instruments should be interpreted and applied 'within the framework of the entire legal system prevailing at the time of the interpretation.' ${ }^{157}$ The application of the doctrine of systemic integration to UN human rights treaties such as the ICESCR and the ICMW allows UN treaty bodies to approach human rights law holistically. As a result, it preserves the integrity of human rights treaties and facilitates a cross-fertilisation process, in the midst of a fragmented landscape. ${ }^{158}$

In its Fragmentation Report, the ILC further indicates how the doctrine should operate by offering two alternatives, relevant to the problems examined in this article. The first alternative requires that the general law rules out the special law, or that the old law rules out the recent law, if 'third party beneficiaries may be negatively affected' by the application of the maxims lex specialis or lex posterior. ${ }^{159}$ For instance, migrant workers' rights protected by the general norms of the ICESCR (with extensive ESC rights) are negatively affected by the specific norms of the ICMW (with restrictive ESC rights). Therefore, according to the Fragmentation Report, the general law (the ICESCR) should rule out the specific law (the ICMW). Furthermore, migrant workers (especially undocumented migrants) are affected by the recent law (the ICMW), since it restricts some ESC rights that have a wider scope under the ICESCR, for instance the right to health. As a result, according to the Fragmentation Report, the older law (the ICESCR) should prevail.

The second alternative offered by the Fragmentation Report, which also provides a rationale to the first, is to preclude the application of the special law or the recent law if it 'might frustrate the purpose of the general law'. ${ }^{160}$ Since UN human rights treaties aim at protecting individuals based on their inherent quality of human beings, ${ }^{161}$ human rights are universal per se. Individuals' migration status should thus, not interfere with the exercise of their ESC rights in theory. This article suggests that UN treaty bodies use the alternatives proposed

156 Legal Consequences for States of the Continued Presence of South Africa in Namibia (South West Africa) notwithstanding Security Council Resolution 276 (1970) (Advisory Opinion) <https://www.icj-cij.org/files/case-related/53/053-19710621-ADV-o1-oo-EN.pdf> accessed 9 September 2020.

157 Ibid, para 53.

158 This holistic method of interpretation is supported by e.g., J. Tobin, The Right to Health in International Law (Oxford University Press, 2012), 104-110.

159 UN Summary Fragmentation Report, ( $\left(\mathrm{n}_{152}\right)$, para 14 (conclusions 10 and 27 ).

160 Ibid, para. 14 (conclusions 10 and 27); UN Fragmentation Report, (n 152), part C (section 5 on regionalism).

161 See their foundational text: UDHR, (n 18), Preamble: 'recognition of the inherent dignity and of the equal and inalienable rights of all members of the human family'. 
by the Fragmentation Report if a conflict of norms arises and the subsequent application of the lex specialis or lex posterior principles restricts the protection of non-nationals' ESC rights. Finally, for cases that neither alternative addresses, the ILC is of the general view that '[i]n regard to conflicts between human rights norms, $[\ldots]$ the one that is more favourable to the protected interest is usually held overriding.'162 This approach, supported by scholars such as Rachovitsa, would give precedence to ICESCR provisions protecting extensively ESC rights, over its Article 2(3) or over the restrictive ESC rights provisions of the ICMW. ${ }^{163}$

In order to assess to what extent UN human rights treaties can contribute to protecting non-nationals' ESC rights, particularly during the COVID-19 pandemic, the above section explored sustainable legal solutions allowing the CESCR and the CMW to deal with restrictive provisions more adequately than by silently dismissing them. It suggested, first, that these UN treaty bodies declared differential treatments based on citizenship impermissible, by upholding the principle of non-discrimination and by applying the test of proportionality, both recognised in the ICESCR and the ICMW. It, then pointed at the relevance of the VCLT rules of treaty interpretation given the conflicting nature of the provisions discussed in this article, but highlighted their inability to give the CESCR and the CMW a crisp answer. Finally, this section emphasised the importance of the recommendations formulated by the ILC in the 2006 Fragmentation Report, allowing these UN treaty bodies to address more comprehensively unresolved issues of treaty interpretation. Together, these legal solutions enable the CESCR and the CMW to put aside incoherent restrictive treaty provisions allowing States to further restrict non-nationals' ESC rights, depleted by the coviD-19 pandemic, by focusing instead on the message conveyed by the legal system in which they operate, thereby increasing too their credibility as quasi-judicial UN bodies.

Austerity policies worldwide have significantly affected non-nationals' ESC rights over the past decade and the CoviD-19 pandemic is exacerbating these inequalities. Therefore, solid legal tools are needed to protect these rights. By

162 UN Fragmentation Report, (n 152), para 108.

163 A Rachovitsa, 'Treaty Clauses and Fragmentation of International Law: Applying the More Favourable Protection Clause in Human Rights Treaties' (2016) 16 Human Rights Law Review 77. 
analysing the extent to which UN human rights treaties can contribute to protecting non-nationals' ESC rights, this article sheds light on the ability of international human rights law to contribute towards addressing the current pandemic.

Section 2 highlighted that while UN human rights treaties follow a historical path of universal aspirations reaching out to non-nationals, they remain chiselled by States and therefore, reflect their fears of 'foreigners'. This is evidenced by the ambiguous protection of non-nationals' ESC rights in the ICESCR, due to its Article 2(3), and in the ICMW, due to the restricted scope of its ESC rights provisions, which clash with the spirit and the text of treaties aimed at protecting the rights of all human beings.

Section 3 then thoroughly analysed the interpretation of these legal ambiguities by the CESCR and the CMW, through their General Comments and through a decade of Concluding Observations following the 2008 economic crisis. It concludes that both UN treaty bodies clearly protect non-nationals' ESC rights by somewhat upholding the principle of non-discrimination and the principle of equality of treatment with nationals. However, their arguments largely fail to rely on a clear legal rationale, thereby perpetuating legal uncertainty for individuals and for States, and damaging their credibility as quasi-judicial bodies.

In response, section 4 suggested alternatives which may help the CESCR and the CMW in developing a more assertive legal framework, by suggesting legal avenues grounded in public international law that justify the effective protection of non-nationals' ESC rights under the ICESCR and the ICMW. Both UN treaty bodies should declare differential treatments based on citizenship unlawful by upholding the principle of non-discrimination and by applying the test of proportionality. They should explicitly rely on the rules of treaty interpretation set in the VCLT to remind States of the universal roots of these instruments. Finally, they should apply the recommendations of the Fragmentation Report to deal with treaty interactions that would otherwise grant less protection to non-nationals' ESC rights.

International human rights law is often compelled to legitimise its existence, at such lengths that it can neglect developing assertive, transparent, and solid normative frameworks around controversial issues such as the protection of non-nationals' ESC rights in key UN human rights treaties. Such a framework, nonetheless, is crucial to mitigate the significant economic and social impact of the COVID-19 pandemic, especially for individuals whose rights are the most likely to be curtailed first: non-nationals. Such a framework is also fundamental to enhance the credibility of UN treaty bodies as quasi-judicial, transparent and accountable institutions; and to combat the legal uncertainty 
surrounding this topic, which is detrimental to both right-holders and dutybearers. By identifying legal ambiguities caused by States' interests and the fragmentation of international law in UN human rights treaties, and by seeking sustainable legal solutions in public international law, this article contributes to discussions on the interpretation of conflicting treaty provisions and the protection of ESC rights in the midst of the COVID-19 pandemic.

\section{Acknowledgement}

I am very grateful to Emily Jermin for her help collating data on a decade worth of Concluding Observations issued by the Committee on Economic, Social and Cultural Rights and the Committee on the Rights of Migrant Workers. Many thanks also to Professor Emily Reid and Professor Andrew Serdy who kindly read previous drafts of this article. Finally, thanks to colleagues who provided helpful feedback during workshops and conferences over the past couple of years, especially colleagues in the ESRAN-UKI network. All errors are exclusively mine. 